\title{
Modes of Thinking in Language Study
}

\section{Jesus Martinez del Castillo}

Department of Philology, Faculty of Business Studies and Tourism, Universidad de Almería, Almería, Spain

Email address:

jesus.gerardo@ual.es (J. M. del Castillo), apofansis@msn.com (J. M. del Castillo)

\section{To cite this article:}

Jesus Martinez del Castillo. Modes of Thinking in Language Study. International Journal of Language and Linguistics. Special Issue: Linguistics of Saying. Vol. 3, No. 6-1, 2015, pp. 77-84. doi: 10.11648/j.ijl1.s.2015030601.20

\begin{abstract}
When we speak of language we usually use the concept of a particular language. In this sense the concept denoted with the word language may vary from one language to another. Real language (=the language spoken) on the contrary, is the reality lived by speakers thus encompassing complex and multifarious activities. Depending on the language spoken, the modes of thinking, modes of being in the conception of things and systems of beliefs transmitted by means of particular languages, denote the living reality of language with different grammatical categories. The concept "language" is expressed sometimes with a noun, thus denoting something existing in it; sometimes with a verb, thus denoting an action or an activity; and sometimes with an adverb, thus denoting the mode of an activity. The reality or degree of reality implicit in these grammatical categories involves a particular mode of thinking, prompted with a particular mode of being in the conception of things. Because of this it is necessary to distinguish the concept of language as something different from the reality of language. But first of all it is necessary to determine the reality or degree of reality of both the reality lived by speakers and the thing usually conceived of as language or a language.
\end{abstract}

Keywords: Mode of Thinking, Mode of Being, the Conception of Things, Language, the Reality of Language, Beliefs, Idiomatic Knowledge

\section{Introduction}

The conception of things has to do with what Coseriu called the original knowledge of speakers, that is, idiomatic knowledge ${ }^{1}$, the original knowledge a human subject has about himself and his free activities. In this you have to separate, at least, two aspects: a) those aspects having to do with language use, and $b$ ) those aspects having to do with beliefs in the conception of things. Beliefs, transmitted through the tradition in the technique of speaking by the different languages, constitute the foundation in the conception of things by speakers. Speaking is speaking, saying and knowing. Human subjects speak because they have something to say. They say because they are both free and historical to know, conceive of things, say and speak ${ }^{2}$. A human subject is at the same time absolute, that is, free, creative $^{3}$ and transcendent ${ }^{4}$; and historical, a subject who

${ }^{1}$ Coseriu 1992, p. 218.

${ }^{2}$ Cf. Martínez del Castillo, 2004.

${ }^{3}$ Cf. Coseriu 1985, 21-23.

${ }^{4}$ The human subject will always aim at something different from the action he performs. Because of this language is a free and end-directed activity, not having performs himself in participation with others in history, thus contingent and limited ${ }^{5}$. Because of this, a human subject creates his mode of thinking, necessarily free and participated, creative and historical, transcendent and limited, and of course individual.

The purpose of a linguistic theory is to understand what language really is, or said in other words: to know what the reality of language is ${ }^{6}$. To do this we must base our theory on the ultimate reality we may find in language analysis, the radical reality ${ }^{7}$. The same as with the act of knowing, a theory is nothing but something we add to the things we apprehend and find in the world. Language is nothing but the reality lived

\footnotetext{
natural or external causes (Coseriu 1988, p. 196).

${ }^{5}$ Cf. Coseriu 1985, 64.

${ }^{6}$ So far, in this special issue, the degree of reality of language has been studied in two articles; first in the concepts of language, a language and speech acts, cf. Jesus Martinez del Castillo. Determining the Degree of Reality of Language. International Journal of Language and Linguistics. Special Issue: Linguistics of Saying. Vol. 3, No. 6-1 , 2015, pp. 39-49; and second, in the activity of speaking, cf. Jesus Martinez del Castillo. The Activity of Speaking. International Journal of Language and Linguistics. Special Issue: Linguistics of Saying. Vol. 3, No. 6-1, 2015, pp. 59-66.

Ortega y Gasset 1996, pp. 40-41. Cf. quotation in $\S 3$, page 6, below.
} 
by speakers, that is, the reality intuited, created, acquired, performed, interpreted, used, evaluated and, even, spoken of and said ${ }^{8}$. Language manifests itself in the speaking behaviour of speakers, that is, it reveals human freedom and intelligence ${ }^{9}$.

\section{Modes of Thinking and Modes of Being}

In this paper I want to pose the problem of language from the ultimate and most radical foundation of it. Once we studied the degree of reality of the concepts "language", "a language", "speech acts"10 and "the activity of speaking", my intention is to compare the conception of language in the minds of the speaking subjects as different from the conception of language by linguists. Speakers live language, as said above, but linguists conceive of language both as speakers and linguists. One of the aspects said in the act of living a language is that speakers usually speak of language in it. Linguists develop this aspect but here the problem lies. Linguistic knowledge, idiomatic knowledge, is a type of knowledge primarily and intuitively justified ${ }^{12}$. The knowledge of language by linguists must start with the intuitive speaking behaviour of speakers and justify it in full ${ }^{13}$. So language is nothing external to linguists. So the basis for a linguist to speak and study language is implicit in the fact that they are speakers and linguists. They live language since language is something coming from their inside, and at the same time they study language as something external to them.

A linguist, when he wants to study language, meets a major difficulty, sometimes invincible: his original conception about language may not be scientific but taken from his linguistic background. A linguist as a speaker has a particular intuitive conception about language and how it functions, especially in the aspects concerning his native language. The interest the linguist feels to know about language makes him be attentive, as a speaker, to all details in language use in a task lasting all over his life. As a consequence when he tries to study language in a justified manner, that is, as a linguist, he will probably try to justify his original ideas, cultivated by him all over his life. But these ideas may be nothing but beliefs, something having emerged in us without any rational support on our part ${ }^{14}$. In this sense, the beliefs in force in our tradition of speaking, that is, in our native language, can make us adopt them as if they were reality itself. A language, as a historical object $^{15}$, transmits a particular conception about things in the

\footnotetext{
${ }^{8}$ Cf. Martínez del Castillo 2013.

${ }^{9}$ Cf. Coseriu 1988, p. 196.

${ }^{10}$ Jesus Martinez del Castillo, Determining the Degree of Reality of Language, International Journal of Language and Linguistics. Special Issue: Linguistics of Saying. Vol. 3, No. 6-1, 2015, pp. 39-49.

11 Jesus Martinez del Castillo, The activity of Speaking, International Journal of Language and Linguistics. Special Issue: Linguistics of Saying. Vol. 3, No. 6-1, 2015, pp. 59-66.

${ }^{12}$ Cf. Coseriu, 1992, p, 218.

${ }^{13}$ Cf. Coseriu, 1992 p. 229; Coseriu 1992, p. 256

14 Ortega y Gasset 2005, p. 172.

${ }^{15}$ Coseriu 1985, p. 17
}

world. One of the most important things in that world is language.

In order to avoid all possible beliefs in language study, the linguist must determine if language really exists or if it can be verified; if language manifests itself and how and what it manifests itself in. He must analyze language to know the degree of reality of it. Language manifests itself in the speaking behaviour of its users. It is nothing abstract but real, the language lived and used by speakers. In this sense and bearing in mind that all speakers bear with them beliefs, we should distinguish three types of behaviour in speakers.

1) First, speakers live their language, that is, they identify themselves with the techniques of expression, the modes of conceiving of things in their language and the beliefs implicit in the mode of conceiving of things, thus constituting a particular historical way of thinking.

2) Second, their language and the techniques of expression in it are historical systems of speaking, that is, something contingent proper of this or that language, not of language.

3) And third, speakers usually speak of things - thus they will give explanation to linguistic facts - in accordance with the mode of thinking in their speech community, their native language.

The techniques of expression of a language bear with them a particular conception of the world, that is, a mode of thinking and a system of beliefs accepted by speakers. As a consequence the original conception of things by linguists is structured in accordance with the original conception of things in force in their native language. Because of this, the original conception of linguists must be analyzed, revised, justified or rejected. Linguists must radically separate language use from the mode of thinking in their language; in other words: they must separate the speaking behaviour of speakers, idiomatic knowledge, something manifesting itself in language use, and the mode of thinking implicit in the explanation of things by speakers and thus in the explanation of linguistic facts.

Due to the system of beliefs transmitted by the western languages the mode of conceiving of things in the western world is peculiar of western civilization. This fact goes beyond language use but it is the support for the conception of things reflected in language use. It constitutes the mode of thinking of westerners, the mode of conceiving of things based on a particular conception of what being means, constitutes or is, the mode of being of things. The mere fact of referring to language with the linguistic category of nouns makes us conceive of the reality of it as something really existing, something there, something independent from anything else, thus something objective, as if it was an entity. The conception of language would be different if the reality of language was denoted with a verb. Compare the different degree of reality in the words language and speaking: they both refer to the same reality but this one is denoted differently ${ }^{16}$. As a matter of fact,

\footnotetext{
${ }^{16}$ To this respect in article [9] we saw the difference in the state of affairs denoted with a noun or a verb, that is, the difference between the what and the how of
} 
in Greek and Latin the reality denoted with what we understand with the concept language was denoted with a verb and an adverb respectively, categories of words used to express different modes of being, an activity on the one hand, or the mode of an activity, on the other. For Coseriu, this way of conceiving of the reality of language related much more exactly to the way of being of real language. In Greek you could find expressions as attikisein (speaking Attic), barbarisein (speaking the language of Barbarians), hellenísein (speaking the language of the Greek). But in Latin this type of referring to the reality of language is even more adequate since the activity of speaking appears separated from its mode: latine loqui, graece loqui (speaking in the mode of speaking of the Latin people, or speaking in the mode of speaking of the Greek) ${ }^{17}$.

In the so-called Old English or Anglo-Saxon, language denoted something in connection with the concept of tribe. The reality of language was expressed with the noun ge.peode, a word in connection with the noun peod (=tribe) but with prefix $\dot{g} e$ - thus referring to the concept of company, and in connection with verb peōdan (=join, gather). It was then the expression of the idea of "joining" "the tribe" (both the prefix and the verb gave the same idea). Now then, "joining a tribe" was only possible through birth. This fact involved the following implications: a) since it was something proper of the tribe, language was something had by the mere fact of being born in this or that tribe. In the world of the Anglo-Saxons, the differences in the language of the tribes constituting the nation of them, were very small, but there were differences; b) since tribes were formed by the same stock of people, that is, by something being transferred genetically, language was something in the nature of the members of a particular tribe. Speakers who spoke the same language belonged to the same ethnic group. So language was universal, but in the sense that it was something belonging to the nature of people belonging to this or that tribe. Because of this, the members of other tribes necessarily had a different language. Language, thus, was something in the human nature but privative of this or that tribe $^{18}$.

For a modern westerner ${ }^{19}$, the reality of language is thought of as if it was something really existing. In this sense it is fundamental to answer the following question, does language

linguistic apprehension of things, lexical meaning and category meaning. Cf. Jesus Martinez del Castillo. Meaning, What is It. International Journal of Language and Linguistics. Special Issue: Linguistics of Saying. Vol. 3, No. 6-1, 2015, pp. 67-76: $\S 4.1$. and $\S 4.2$. pp. 72 and 73.

${ }^{17}$ Coseriu 1992, pp. 78-79.

${ }^{18}$ It is worth noticing that some theories about language today, formulated by English speaking linguists, consider language as something innate and natural. The concept of $\dot{g}$ e.peode has been transmitted in the tradition of speaking of the English Language associated to a foreign word language but the conception of it has persisted so far. As a matter of fact, the word language was introduced in English in the late $13^{\text {th }}$ century coming from Old French langage.

${ }^{19}$ This expression should be understood as referring to the so-called Western World, the culture having started with the Old Greek and extended all over the world, today represented in the culture prompted by the European languages. It opposes the Eastern World, the Indian, Chinese, Japanese cultures and the like. exist? (Or, how does it exist?), Can language be verified? How does language manifest itself? The answer to these questions may help us find out the peculiar way of thinking and the implicit way of conceiving of things in every case.

\subsection{Modes of Thinking: The Concept of Substantive Being}

In the history of Thought-referring this expression to western thought - the concept of being, that is, the concept of how things are to be conceived of - the mode of being and thus the mode of thinking - varies largely due to the intervention of the great thinkers in the western philosophy. The original and underlying conception of things in western languages is what we call the substantive being ${ }^{20}$, a concept originally in force all around the Mediterranean, transmitted by our languages ${ }^{21}$.

The first Greek thinkers, Parmenides of Elea and Heraclitus of Ephesus, $6^{\text {th }}$ century BC, conceived of things as if they really existed. Being, for them, was something existing as opposing naught thus something objective, both being and naught having the same degree of reality. Parmenides said that you cannot say anything about being, the only thing you can say is that "being is and it is impossible for it not to be"; and together with this he added, "non-being is not and you cannot even speak of it" 22 . That is, being and non-being (=naught) have the same degree of reality; both existed at the same level or, said in accordance with Heraclitus' conception: being is in opposition to naught ${ }^{23}$. For Parmenides, being is one, eternal, immobile, it has no beginning or end ${ }^{24}$. In the history of Thought this conception by Parmenides meant attributing lógos to reality, that is, dispossessing reality of the subjective, thus becoming lógos (=both thought and saying) ${ }^{25}$.

For Heraclitus of Ephesus, being is nothing static or inert but something opposing its contrary. Ortega y Gasset paraphrases this conception in this way: I am in as much as I oppose the world; the world opposes me and obliges me to act in opposition to it. Without the world I would not be ${ }^{26}$. Heraclitus's conception meant the introduction of lógos in reality as well, dispossessing reality of the subjective. With this lógos was common, something in all human beings ${ }^{27}$.

This mode of thinking, the concept of substantive being, created innumerable metaphysical problems, one of them, the problem of movement: being cannot change because changing involves that something not existing previously, now exists.

\footnotetext{
${ }^{20}$ Ortega y Gasset 1971, p. 38.

${ }^{21}$ The major manifestations of substantive being in the western world can be found in the following three facts: a) the concept of science. Science in the West aims at dominating the object of study, things in the world. In the Asian world, science is connected to individual happiness, Wisdom. That is, science in the West is objective; in the East, subjective; b) monotheism. The three monotheist religions were born around the Mediterranean. Monotheist religions are absolute, they all claim to be the true one; and c) things are conceived of as if they really existed or were there.

${ }^{22}$ Cf. Ferrater Mora, Diccionario de filosofia, RBA, four volumes.

${ }^{23}$ Ortega y Gasset 1992b, p. 217.

${ }^{24}$ Cf. Ferrater Mora, Diccionario de Filosofía.

${ }^{25}$ Ortega y Gasset, OC, IX, p. 1063.

${ }^{26}$ Cf. Ortega y Gasset 1994, p. 117; Ortega y Gasset 1994, p. 264.

${ }^{27}$ Cf. Ortega OC, IX, p. 1063.
} 
Before this untenable situation from the level of the real, Aristotle, $4^{\text {th }} \mathrm{c}$. BC, reacted trying to conciliate both previous conceptions thus adding a new one. For Aristotle, the concept

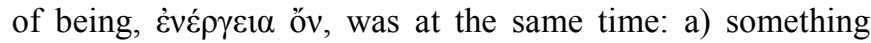

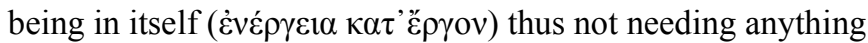
else to be (=substance); b) something executing itself

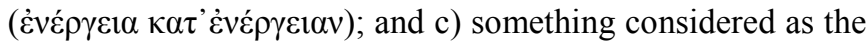

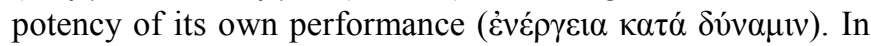

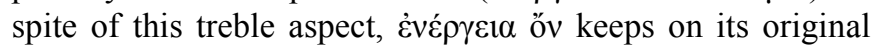
character: something there, being objectively ${ }^{28}$, standing in front of us.

The concept of substantive being in force in Greek and Mediterranean cultures-Parmenides and Heraclitus did nothing but formulating what was in force in their speech community - has become the mode of conceiving of things in the western civilization, a concept of being not in force in other parts of the world outside the western civilization ${ }^{29}$.

Substantive being applied to language makes us think of language as something there, objective, opposing its contrary (=non-language), not needing anything else to be, existing apart from speakers, that is, language as an entity. In this sense language is thought to constitute part of the world, apt to be described in it. As a consequence, you can take the existence of language as the initial asset for its study. As a matter of fact most modern theories about language start with this conception of language ${ }^{30}$.

\subsection{The Modern Mode of Being: The Cartesian Mode of Thinking}

René Descartes (1596-1650) revised the mode of thinking of substantive being, and proposed the "I" and "Thought" as the radical reality in the conception of things thus creating a new mode of thinking. He stated, "cogito, ergo sum". That is, because I can think I can conclude that I am. In this way and after him, being is something manifesting in thought, based on three pillars, intuition, reason and deduction ${ }^{31}$. To intuit, for Descartes, is finding out necessary connections in things thus appearing evident ${ }^{32}$, that is, executing reason in the contemplation of things. When you analyze concepts and find out new connections, then you have deduction, a new function of the mind different from intuition ${ }^{33}$ and reason. With this conception the character of philosophy changed: before Descartes philosophy asked for being-What is being? - but after Descartes philosophy asked for the way how being is known - How is being known? That is and said in other words: before Descartes reality existed in it; after Descartes reality existed in thought.

So today the concept of being transmitted by our languages

\footnotetext{
${ }^{28}$ Cf. Ortega y Gasset 1992, pp. 277-278.

${ }^{29}$ The concept of substantive being does not exist in the tradition of Hopi, people living in Little Colorado Valley (cf. Whorf 1956, p. 258) or in Ewe, a language in Togo (cf. Benveniste 2007, vol. I, pp. 71-72).

${ }^{30}$ Cf. Martínez del Castillo, 2012; Martínez del Castillo, 2010.

${ }^{31}$ Cf. Ortega y Gasset,1992a: 148 \& ff.

32 Ortega y Gasset, 1992a, p. 328.

${ }^{33}$ Cf. Ortega y Gasset 1992a, p. 331.
}

(substantive being) radically opposes the way of thinking introduced by Descartes and philosophy after him. Speakers of the western languages refer to the reality of language as something there, existing in it objectively, independent from the reality it appears in, that is, something with no or little connection with its creators, speakers. As a consequence and because of this, you can pose the metaphysical problem of asking if language exists or if it is something created by the human thought.

A metaphysical problem is the one posed in terms of contraposition of the concrete and sensitive, given to us by our senses, and the mental, invented or fabricated by us. In the apprehension of things - the apprehension of being - our senses play an important role. Immanuel Kant (1724-1804) established two sources for knowledge, sensibility and intellect, also called, respectively, receptivity and spontaneity. For Kant, knowledge is performed as the synthesis of both faculties, that is, as a unification of the multiple forms of sensibility by means of the intellect through forms a priori. The synthesis of sensibility and intellect is possible because of imagination. Imagination is a creative force present in the base of both receptivity and spontaneity. In the synthesis of knowledge made by imagination, both faculties converge ${ }^{34}$.

Metaphysical problems can be summarized in the problem of knowledge: What do we know? Do we know because of our senses? What do our senses contribute to knowledge with? Does Man know only through his senses or does he create what he says he knows? At first sight, we can see that the human knowledge does not relate to the thing given by our senses. In order to know, it is necessary at least to change the thing given by our senses and add something else to $\mathrm{it}^{35}$.

The double reality of knowledge stated by Kant is present in language and its verification. We as speakers can verify the existence of language in our daily life. We live language, that is, we intuit, create, acquire, perform, speak and say, interpret, use, evaluate and, even, speak of. In this sense language is real. But, on the other hand, language in as much as it appears and is denoted in the word by means of the concept "language", poses the problem of its existence and verification. Language cannot be verified in it. This means that language does not exist or at least that language does not have concrete existence. You can verify language indirectly as it manifests in something else. Language is good for speaking, saying, knowing and thinking, good for us at manifesting ourselves to others and good for others at manifesting themselves to us, good at structuring and re-structuring the world, good at knowing and making science, good, in a word, at making possible the existence of human beings in the world. Humans cannot do anything unless through language even when they are alone or think. In this sense, language exists. The problem is to explain how language exists and what extent language is real. The problem with language study thus is to determine the degree of reality it has. The reality of language is not simple

\footnotetext{
${ }^{34}$ Kant 2004, pp. 47-52; Di Cesare 1999, pp. 35-36.

35 Ortega y Gasset 1989, pp. 41-42.
} 
but complex. It must be guessed out and devised. The first thing to do then is to study language as it manifests itself. We cannot take language as constituting an easy reality. Language is a phenomenon (from $\varphi$ aív $\omega=$ make things clear,

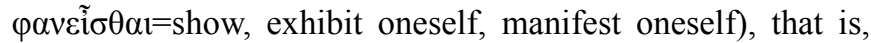
something existing but mentally, manifesting itself in something else ${ }^{36}$.

\subsection{Modes of Thinking in the $20^{\text {th }}$ Century}

In the history of Thought different modes of thinking manifested themselves in the 20th century. We can summarize them in three:

a) Being as a phenomenon, that is, being as manifesting itself. Things are things in so far as they are useful, that is, as they play a function. A chair, for example, made in wood, if we burn it to warm up it is not a chair (=a piece of furniture to sit on) but firewood. In this sense, things manifest themselves in front of us;

b) Executive being, the mode of being in which you live things, thus things acting on you ${ }^{37}$. Something is in the way it is because it executes what it is. Light is something I need, thus being what I expect it to be; nevertheless I shall not consider or mention it unless it is missing. Thus light acts on me.

c) Being as reality. Something is in terms of the action I may execute on it and at the same time it acts on me. For Ortega y Gasset, reality means sheer action of the circumstance on me and me on the circumstance ${ }^{38}$. Language is nothing but the thing I create, acquire, perform and use. Its reality consists in my creating, performing and using it. In this sense things are in so far as they relate to the perspective the cognizant subject imposes on them.

Language for the speaking subject is to know how to speak, that is, it is the idiomatic knowledge the speaking subject lives, that is, intuits, creates, acquires, performs, speaks and says with, uses, evaluates and even speaks of. For the listener, language basically is the act of understanding. The speaker and the listener live language, but differently. Since the speech act is made up of both the speaker and the listener, relieving each other in their respective roles, and since living is conscious, language is both speaking and understanding,

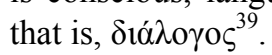

But, on the contrary, for a linguist, language is merely a cognizant object, that is, an object conceived of and apt to constitute the object of a theory. At the same time, if for speakers, language is a unitary reality they "live", for a linguist, it may be something made up of many aspects. Linguists usually separate different levels constituted with sounds, words and word-formation, the combination of words, meaning, the production of speech, texts and the

\footnotetext{
${ }^{36}$ Cf. Heidegger 2002, p. 37.

${ }^{37}$ Ortega y Gasset 1992b, 127.

${ }^{38}$ Ortega y Gasset, 1992b, p. 127.

${ }^{39}$ Ortega y Gasset, 1987: 16; Coseriu 1985, p. 15; Coseriu 1988, pp. 70-71.
}

content created beyond meaning (saying). Every one of these levels can constitute a branch of knowledge thus forming different disciplines, independent from one another, and to a certain extent independent from the initial conception of language: phonology, morphology, syntax, semantics, text linguistics and linguistics of saying.

The problem when studying language is analyzing what the reality of it is, or what degree of reality it has. When you refer to language you denote a very vast and complex reality: a set of connections you must find out and separate.

\subsection{Language Study as an Act of Knowing}

For a cognizant subject, to study something is an act of knowing ${ }^{40}$. This is nothing but the attempt to capture the essence, consistency or reality of things. So in the act of knowing we can see the following elements. First, the cognizant subject: human knowledge is active, something made by an intelligent and creative subject.

Second, the object known. For Kant, knowledge is the synthesis of the thing given by our senses, sensibility, and the intellect through forms a priori. Forms a priori are those statements in the understanding of which you do not need experience. For forms a priori to be, it is necessary the synthetic connection of intuition ${ }^{41}$. Forms a priori are analytic, that is, the extent of the content of both the syntactic subject and the predicate of a statement is the same. For example, you can say $5+7=12$. Either if you count the sum in the syntactic subject with your fingers or a calculator you will see that the predicate is 12 . Analytic statements are necessary and universal, something given in the very formulation or statement of them. However they are not evident, something you can verify, in the example, if you operate with larger digits.

And third, the synthetic connection of intuition. In extensive statements, those in which the extent of the predicate goes beyond the thing stated in the subject, the synthesis consists in attributing necessity and universality to sensibility. That is, you add something mental not existing in the percept coming to you through your senses. The synthesis determines the conception of the object known just transformed and made into an image of it because of imagination. These are synthetic a priori statements.

Synthetic a priori statements are based on analogy $y^{42}$. If you know a few facts of experience, all of them similar in their nature, reality, essence or consistency, you can assume that all items constituting the same class (or category) have the same nature, reality, essence or consistency as the ones you first knew. Synthetic a priori statements can even be made on the base of only one item. In both cases the particular items are made into the image of the class they represent ${ }^{43}$. The reason of this is that on the base of the few examples you experienced, you intuitively

\footnotetext{
${ }^{40}$ I'd say act of knowing rather than act of knowledge because the first expression is active.

${ }^{41}$ Cf. Kant 2004, p. 49.

42 Ortega y Gasset, 1992a, pp. 226-230.

${ }^{43}$ Ortega y Gasset 1992b: 152.
} 
and based on analogy define the class of items they belong to. For example, Oil will float on water. This statement has a priori force in the synthesis made, since you add universality and necessity to something you experienced as a sporadic and temporary fact. The statement is not analytic but extensive and thought of a priori, a synthetic a priori statement ${ }^{44}$.

The synthesis of sensibility and intellect is present in the formulation of theories. Synthetic a priori statements in science are usually called assumptions, principles or even hypotheses. You assume that the object known, once it is added necessity and universality, is in the way stated. Because of this the intellect will look for the execution of it in real things since the statement represents the image, that is, the essence of something real. In this sense a theory is the result of imagination, something invented by the scientist.

In the synthesis of sensibility and intellect the mode of thinking or rather the mode of conceiving of things, plays an important role. As we saw earlier, modes of thinking, especially the one based on the substantive mode of being, constitute beliefs. Because of this, assumptions may be based on beliefs not formulated or analyzed. So the major assignment when analyzing a theory, or an act of knowing, is determining the ultimate reason prompting the formulation of the assumption. In this sense, the ultimate reason (assumption, principle or hypothesis) plays a function similar to what Ortega y Gasset calls the radical reality. The determination of the radical reality plays a decisive role in human studies because human subjects are free, absolute and transcendent, always aiming at something different from the actions performed; and at the same time they are together with others, thus being social ${ }^{45}$.

\section{The Radical Reality}

For Ortega y Gasset, human beings do not have a static mode of being. The human way of being for a human being is nothing prior to their birth, nothing given or made, but something to be made in struggle with the circumstance the human subject is $\mathrm{in}^{46}$. The circumstance the subject is in is determined by the moment in history it occurs. Any one of the many possible modes of being a human being finds constitutes a fundamental experience, which, once performed, may constitute a limitation and be the reason for a new one ${ }^{47}$. Since human subjects are together-with-others ${ }^{48}$, that is, since they constitute society based on $\delta i \hat{\alpha} \lambda \mathrm{o} \gamma \mathrm{o}$, , language and the mode of thinking in force in a particular speech community are participated $^{49}$. All human subjects living in a speech community at a particular moment of history have similar modes of thinking. They all share common ${ }^{50}$ modes of

\footnotetext{
${ }^{44}$ Kant 2004: 47-52.

${ }^{45}$ Coseriu 2006, p. 44.

${ }^{46}$ Ortega y Gasset, 1994, p. 190.

${ }^{47}$ Ortega y Gasset 1996: 236-237.

${ }^{48}$ Coseriu 2006: 44

${ }^{49}$ Coseriu 1988: 43.

${ }^{50}$ Coseriu, 1988, p. 70.
}

conceiving of things and the world. This constitutes the historical reason, for Ortega y Gasset ${ }^{51}$ and the condition of "otherness" for Coseriu ${ }^{52}$. Ortega y Gasset says,

A man lives amongst a multitude of things and modes of being of those things, real modes of being of those things. This obliges us to look for the maximum or highest reality, or radical reality, to be used as the unit of measuring the others, in order to settle them down and range in a ontological hierarchy in being thus basing them on being ${ }^{53}$.

In some way or another our thought is structured. We can base our hierarchy of things known either by ourselves finding out the radical reality they are based on, or accept the hierarchy of things given to us in our historical tradition ${ }^{54}$. A linguist must find out the radical reality of language or else he will accept the ultimate reason his historical mode of thinking bears with it. The radical reality cannot admit anything prior to it. In this sense, it is necessary to designate both realities with different names. For the ultimate reason I mean the set of beliefs transmitted by our language, structured in it in so far as the different beliefs in it are arranged or systematized with the meanings of a language. On the contrary, following Ortega y Gasset, for the radical reality I understand the reality found out by us through analysis and rational study.

The ultimate reason, as opposing the radical reality, since it was not thought but accepted, entirely depends on the conception speakers have about things, that is, on the mode of thinking and the implicit mode of being received from tradition. In order to find out the radical reality the question to be made is different in any case. For the mode of thinking of substantive being, the question is, does language exist? Can language be verified? On the contrary, for the modern mode of thinking, being as it is intuited, the question is, why is language universal and necessary in humans? For the executive mode of thinking (conceiving of things in as much as they help, or prevent us from, doing something, the question is, what is language for speakers? For the mode of thinking of being as manifesting it, the question is, how does language manifests itself? Is language anything autonomous or something being given in something else? And finally, for the mode of thinking of being existing as real, the question is, is language real? What is the degree of reality of language?

In the following example we can see the role of the ultimate reason, as opposing the radical reality, plays in language study. Language, for a particular linguist, may be a mysterious ${ }^{55}$ faculty $^{56}$, a common human possession, varying little across the species ${ }^{57}$, something you can describe only in the process of language learning ${ }^{58}$. Because of this language must answer the innate schemata of learning thus revealing linguistic

\footnotetext{
${ }^{51}$ Ortega y Gasset, 1996, pp. 120-122.

${ }^{52}$ Coseriu, 2006, p. 44

53 Ortega y Gasset 1996, pp. 40-41; my translation.

${ }^{54}$ Cf. Coseriu 1988, p. 70.

${ }^{55}$ Chomsky, 2002, p. 59

${ }^{56}$ Chomsky 2002, p. 47.

${ }^{57}$ Chomsky 2002, p. 47.

${ }^{58}$ Chomsky 1965, p. 27.
} 
universals and universal grammar ${ }^{59}$. As a consequence language is innate and natural ${ }^{60}$.

The linguist in question may have experienced that he could not explain language in a particular moment and then he may have felt entitled to conclude, based on analogy, that "language is mysterious". With this assumption, the statement is not about the fact that an individual linguist once experienced the referred to difficulty, but a synthetic a priori statement, contemplating connections in it: necessity and universality (=language is and will always be mysterious). Once you have analyzed the first assumption you may proceed in the same way with the other assumptions, namely, that language is a faculty "necessarily and universally", a common human possession, varying little across the species (necessarily and universally), something you can describe - thus assuming it is true- only in the process of language learning (necessarily and universally). In consonance with these you can conclude that there are linguistic universals revealing a universal grammar, and eventually that language is innate, belonging to human psychology ${ }^{61}$ and thus natural ${ }^{62}$.

But let us analyze what is the ultimate reason in the conception of these statements. Language is mysterious, a faculty, a common human possession, varying little across the species, etc. because language is something, that is, language exists with concrete existence, the same as the "human visual system" 63 which is based on a specialized organ, the eyes. But language cannot be the ultimate reason because we have said that it has not concrete existence, that is, we cannot verify it directly. Considering that some languages, for example, English and German, identify the realities of language and a language, the ultimate reality cannot be but the way the concept of language is conceived of: language constitutes a unit in it thus it is something existing somewhere, something standing in it, that is, existing, and not needing anything else to exit. The ultimate reason, thus, is the concept of being transmitted by western languages, in force in the western world, coming to us from the Greek: substantive being.

The problem, then, is finding out whether these assumptions are true or not. Language, the subject in those statements, does it exist? Can it be verified? The analysis we have just made can be made summarized in terms of the statements they constitute. For language to be mysterious, it must be something; for language to be a faculty, it must be something similar to other faculties, something objective depending on organs; for language to belong to the human species, it must be something as well since a species manifests itself in individuals with a body; for those linguistic universals and universal grammar to exist, it is necessary that language should exist; for language to be learnt, it should exist, the same as those innate schemata. So you conceive of language as

\footnotetext{
${ }^{59}$ Chomsky 1965, p. 25.

${ }^{60}$ Chomsky 1965, pp. 25-27.

${ }^{61}$ Cf. Chomsky 1992, p 57; Chomsky 1992, p. 124 and 126; Chomsky 1992, p. 175

${ }^{62}$ Cf. Noam Chomsky, 2000, p. 106

${ }^{63}$ Cf. Chomsky 2000, pp. 106-107.
}

something in the human nature existing objectively in the human psychology ${ }^{64}$ or the psychology of the mind ${ }^{65}$.

But here the problem lies: is this conception real? If language is something objective and natural it must be verified in what it is. Is language verified in real terms? How can language be verified?

But language cannot be verified in itself. It can only be verified in speech acts. Prior to the conception of language as something existing in it, it is the problems of the manifestation of language and the reality of language. Language and its manifestations are merely concepts, something got through abstraction. You will say language, a language, speech or a speech act, when you verify people speaking. At the same time it is the problem of reality of language or the degree of reality it has and the degree of reality of speech as an activity. And when we know all this it is necessary to find out the radical reality language is based on.

The radical reality of language cannot be but human subjects who speak because they have something to say; who say because they define themselves before the circumstance they are in and compromise before that circumstance making a statement out of it because they are able to know ${ }^{66}$.

\section{Conclusions}

All modes of thinking and the implicit modes of being have to do with the original conception of language both for speakers and linguists. Speakers live language, that is, they intuit language (modern mode of thinking); create, acquire and perform language (executive mode of thinking); speak, say and know in accordance with historical traditions (mode of thinking of being as manifesting itself). For speakers,

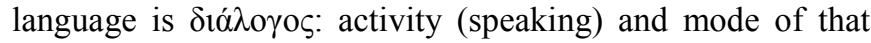
activity (a particular language); they use language thus making themselves human (mode of thinking of being as reality); they speak of language as a series of entities (language, the English language, meanings, words, speech, speech act, speech sounds, the correct use of words, etc.) (substantive mode of thinking).

But linguists will usually have to consider language as an object. Since linguists are at the same time speakers their study of language must be hermeneutics, that is, interpretation. Language thus must be described in its birth when it is conceived of and uttered by speakers.

Correspondingly, all modes of being are necessary in the study of language:

a) Language study involves the creation of a theory, series of synthetic a priori statements (modern mode of being).

b) Language study is the description of the speaking behaviour of speakers, either individually or in participation with others in a speech community thus revealing human intelligence and freedom (executive

\footnotetext{
${ }^{64}$ Chomsky 2002, pp. 61-64.

${ }^{65}$ Chomsky 2002, pp. 61-64.

${ }^{66}$ Martínez del Castillo, 2004.
} 
being).

c) Language study reveals language as activity and a mode of that activity, that is, subjects speak, say and know in a particular language (being as manifesting itself).

d) Language and all aspects in it are to be described in the degree of reality they have, bearing in mind the radical reality they are based on (being as real).

e) The description of language and its manifestations cannot be made unless they are conceived of as entities (substantive being).

Language is nothing but human subjects who know, define themselves before the circumstance they are in, compromise, say and speak thus making themselves human and manifesting themselves to others.

\section{References}

[1] Benveniste, Émile, Problemas de lingüística general, vol. I, Siglo XXI Ediciones, 2007, [1971].

[2] Chomsky, Noam, Aspects of the Theory of Syntax, Cambridge, Mass: The MIT Press, 1965.

[3] Chomsky, Noam, El lenguaje y el entendimiento, Planeta-Agostini, 1992 [1968].

[4] Chomsky, Noam, New Horizons in language study and Mind, Cambridge University Press, 2000.

[5] Chomsky, Noam, On Nature and Language, Cambridge University Press, 2002.

[6] Coseriu, Eugenio, El hombre y su lenguaje, Estudios de teoría y metodología lingüística, Madrid: Gredos, 1985 [1977].

[7] Coseriu, Eugenio, Sincronía, diacronía e historia: el problema del cambio lingüístico, Madrid: Gredos, 1988 (1957).

[8] Coseriu, Eugenio, Competencia lingüística. Elementos de la teoría del hablar. Madrid: Gredos, 1992 [1988].

[9] Coseriu, Eugenio y Óscar Loureda, Lenguaje y discurso, Pamplona: Eunsa, 2006.

[10] Di Cesare, Donatella, Wilhelm von Humboldt y el estudio filosófico de las lenguas, tr. Ana Agud, Barcelona: Anthropos, 1999.

[11] Ferrater Mora, José, Diccionario de filosofía. RBA, 5 vols.

[12] Heidegger, Martin Heidegger, El ser y el tiempo, tr. José Gaos. RBA, 2002 [1944].

[13] Kant, Immanuel, Crítica de la razón pura, RBA, 2004.
[14] Martínez del Castillo, Jesús, La intelección, el significado, los adjetivos, Universidad de Almería, 1999.

[15] Martínez del Castillo, Jesús, La lingüística del decir. El logos semántico y el logos apofántico, Granada: Granada Lingvistica,

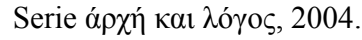

[16] Martínez del Castillo, Jesús, «Hablar, decir y conocer: el acto lingüístico», Oralia, 11 (2008): 375-97.

[17] Martínez del Castillo, Jesús: «El logos semántico y el logos apofántico» Enérgeia I, Online-Zeitschrift für Sprachwissenchaft, Sprachphilosophie und Sprachwissenschaftsgeschichte. 2009: 50-80.

[18] Martínez del Castillo, Jesús: Las relaciones lenguaje-pensamiento o el problema del logos. Madrid: Bilbioteca Nueva, 2010.

[19] Martínez del Castillo, Jesús, Sobre las categorias, Buenos Aires, Deauno.com, 2011.

[20] Martínez del Castillo, Jesús, ed. Eugenio Coseriu (1921-2002) en los comienzos del siglo XXI, 2 vols. in Analecta Malacitana, Anejos/86, 2012.

[21] Martínez del Castillo, Jesús: Psicología, lenguaje y libertad, in Analecta Malacitana, Anejos/89, Universidad de Málaga, 2012.

[22] Martínez del Castillo, Jesús: Modes of Thinking, Language and Linguistics, in Analecta Malacitana, Anejos/94, 2013, Universidad de Málaga.

[23] Ortega y Gasset, José, Historia como sistema, Alianza Editorial, 1971 [1935].

[24] Ortega y Gasset, El tema de nuestro tiempo, Alianza Editorial, 1987 [1981].

[25] Ortega y Gasset Goethe, Dilthey, Alianza Editorial, 1982.

[26] Ortega y Gasset, José, La idea de principio en Leibniz, Alianza Editorial, 1992a [1958].

[27] Ortega y Gasset, José, ¿Qué es conocimiento?, Alianza Editorial, 1992b [1984].

[28] Ortega y Gasset, José, Notas de Trabajo. Epílogo, José Luis Molinuevo, ed. Alianza Editorial, nº 417, 1994.

[29] Ortega y Gasset, José, Sobre la razón histórica, Colección Austral, Espasa-Calpe, 1996 [1979].

[30] Ortega y Gasset, José, Obras Completas, 10 vols. Madrid: Fundación Ortega y Gasset-Taurus, 2004-2010.

[31] Whorf, Benjamin Lee Whorf, Language, Thought and Reality: Selected Writings of Benjamin Lee Whorf. John B. Carroll, ed. Cambridge, Massachussets: The MIT Press, 1956. 